\title{
The Principal's Role as Manager and Teacher Pedagogic Competence in Online Learning
}

\author{
Nur Ngazizah1 ${ }^{*}$, Umi Pratiwi2, Siska Desy Fatmaryanti ${ }^{3}$, Aulia Fakhrina ${ }^{4}$, Rizky \\ Fadjar Choirrul Linda ${ }^{5}$ \\ 1,4,5 PGSD Universitas, Muhammadiyah Purworejo, Purworejo, Indonesia \\ 2,3 Pendidikan Fisika, Universitas Muhammadiyah Purworejo, Purworejo, Indonesia
}

\section{ART I CLE I N F O}

\section{Article history:}

Received July 29, 2021

Revised July 30, 2021

Accepted September 30, 2021

Available online November 25, 2021

\section{Kata Kunci:}

Kepala Sekolah, Kompetensi Guru,

Pembelajaran Daring

\section{Keywords:}

Principal, Teacher Competence, Online Learning

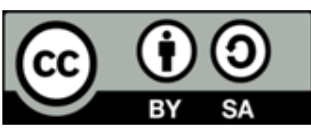

This is an open access article under the CC BY-SA license.

Copyright (C) 2021 by Author. Published by Universitas Pendidikan Ganesha.

\section{A B S T R A C T}

\begin{abstract}
A B S T R A K
Pandemi Covid-19 menuntut masyarakat untuk belajar secara daring salah satunya pada jenjang Sekolah Dasar. Kepala sekolah harus mampu berperan sebagai manajer dalam mengelola pembelajaran selama Pandemi Covid-19. Penelitian ini bertujuan untuk menganalisis peran kepala sekolah sebagai manajer dan kompetensi pedagogik guru dalam pembelajaran daring pada masa Covid-19. Jenis penelitian ini adalah penelitian deskriptif kuantitatif, yaitu dengan menginterpretasikan data yang diperoleh dari lapangan. Pengambilan data dilakukan pada 4 Kepala Sekolah dan 49 Guru dengan menggunakan angket yang disebarkan melalui google formulir. Analisis data menggunakan deskriptif kuantitatif dengan persentase. Hasil penelitian menunjukkan bahwa peran Kepala Sekolah sebagai manajer dalam pembelajaran daring belum optimal pada indikator Sekolah menentukan kurikulum yang digunakan pada pembelajaran daring (44\%) dan Kepala sekolah memfasilitasi penunjang dalam pembelajaran daring (50\%), sedangkan pada kompetensi pedagogik juga menunjukkan kurang optimalnya dalam memerankan kompetensinya ditunjukkan 5 indikator persentase terendah, meliputi memahami perkembangan kognitif peserta didik (59\%), merancang metode pembelajaran (52\%), merancang model pembelajaran (56\%), melaksanakan penilaian hasil belajar (54,5\%), dan melakukan pengkajian materi (56\%). Dengan komitmen yang kuat dari para guru dan kepala sekolah, berbagai upaya dan program yang dilakukan selama pembelajaran online membuat tujuan pembelajaran akan tercapai secara maksimal.
\end{abstract}

\begin{abstract}
The Covid-19 pandemic requires people to learn online, one of which is at the elementary school level. Principals must be able to play a role as managers in managing learning during the Covid-19 Pandemic. This study aims to analyze the role of the principal as a manager and the pedagogical competence of teachers in online learning during the Covid-19 period. This type of research is descriptive quantitative research, namely by interpreting the data obtained from the field. Data collection was carried out on 4 principals and 49 teachers using a questionnaire distributed via google forms. Data analysis used descriptive quantitative with percentages. The results showed that the principal's role as a manager in online learning was not optimal in the indicators of the school determining the curriculum used in online learning $(44 \%)$ and the principal facilitating support for online learning $(50 \%)$. At the same time, the pedagogic competence also showed less than optimal in Playing their competencies is shown by the 5 lowest percentage indicators, including understanding the cognitive development of students $(59 \%)$, designing learning methods (52\%), designing learning models (56\%), carrying out assessments of learning outcomes $(54.5 \%)$, and conducting material assessments. (56\%). With a strong commitment from teachers and principals, various efforts and programs carried out during online learning will optimally achieve learning objectives.
\end{abstract}

\section{INTRODUCTION}

The implementation of online learning in Indonesia regarding the Implementation of Educational Policies in Emergencies results from the spread of the Covid-19 virus (Dhawan, 2020; Nurkholis, 2021; 
Yulia, 2020). Covid-19 has had a considerable impact on all walks of life, without exception in education (Guswara, 2020; Kimkong Heng \& Koemhong Sol, 2020; Korkmaz \& Toraman, 2020). During online learning, the principal must be able to carry out his role as a manager, namely the role of the principal in managing all learning activities during the Covid-19 Pandemic (Huang et al., 2021; Zhou et al., 2021). The principal is the highest leader in an educational institution responsible for everything related to school activities to realize school goals (Albu, 2013; Ingemarson et al., 2014). The highest leader in educational institutions, namely the principal, has the duty and responsibility to lead a school by utilizing all the existing potential with full responsibility for learning in schools (Muliartini et al., 2019). In addition, the principal is a pioneer in schools who have the obligation and authority to direct, supervise and select all supporting activities related to teaching and learning activities in schools so that school goals can be achieved (Kadarsih, Inge. Marsidin, Sufyarma. Subandi Ahmad, 2020; Ratmini et al., 2019). The implementation of the obligations and duties of the principal as a pioneer is indispensable in managing and organizing all school activities, which are expected to be able to realize the educational goals that have been previously planned. Namely, developing the potential of human resources, forming and making school components work closely with all components to achieve school goals to the fullest (Ikbal et al., 2019; Maris et al., 2016; Mustikaningrum et al., 2020).

The principal, in this case, plays an essential role in determining policies that are by the conditions during the Covid-19 Pandemic. Principals must act decisively in determining appropriate policies to current crisis or emergency conditions (Muliartini et al., 2019; Ratmini et al., 2019). The principal must manage all the potential and resources of the school to function optimally in the conditions of the Covid-19 Pandemic. It can be done if the principal can carry out his role as a manager (manager). It can be said that the progress of a school is highly dependent on the role of the principal as a pioneer in leading and managing schools (Maris et al., 2016; Yusuf, 2012). One of the principal's roles is as a manager (manager). The principal is a planner, organizer, leader and school controller (Subandi, 2018; Widodo, 2014). It is adjusted to the management functions, namely planning (planning), organizing (organizing), implementation (actuating), controlling (controlling) (Darmalaksana et al., 2020; Wuryandani et al., 2014). As a manager, the principal has the task of managing school resources, including school planning (RKS and RKAS), managing educators, namely teachers and employees, managing students, managing finances, managing facilities and infrastructure, and all supporting components can be utilized to the fullest. possible to achieve school goals (Yahdiyani et al., 2020; Kadarsih, et al., 2020). When online learning takes place, of course, there are inhibiting factors, and when online learning takes place, there are inhibiting and supporting factors in managing online learning from the school (Hutauruk \& Sidabutar, 2020; Rigianti, 2020a, 2020b). Schools, in this case, the principal, are required to manage school management well in times of crisis like today, namely by preparing and managing emergency or unexpected situations that affect students, teachers, parents, and schools by implementing different school management with conditions before the Covid-19 pandemic (Ali, 2020; Dhawan, 2020; Yulia, 2020). Based on the interviews with several principals, it was explained that the principal has a role in learning management which includes planning, implementing, supervising and evaluating the online learning process. Initially, schools had difficulty implementing online learning due to the limited availability of facilities and infrastructure. However, school principals try to work closely with teachers, parents, students, committees and foundations so that online learning can run well. With policies issued by schools and support from several parties, online learning is no longer complex (Maulana \& Hamidi, 2020; Mpungose, 2021; Wijaya et al., 2020).

In implementing school management, principals need teachers to maximize their policies (Ikbal et al., 2019; Mustikaningrum et al., 2020). As a manager, the principal must be able to mobilize, influence, supervise and strive for the components of the school he leads to work together in achieving educational goals and school goals. Teachers are one of the human resources in educational institutions (Bosica et al., 2021; Sutarto et al., 2020; Taştan et al., 2018). Teacher competence in schools plays an important role, one of which is the achievement of school goals. Teacher competence is a reflection in professional or not learning, more specifically in online learning situations (Mahmoodi et al., 2019; Sutarto et al., 2020). The implementation of online learning as a learning arrangement with a new style triggers challenges and obstacles. Therefore the ability of teachers is tested (Adiningtiyas, 2017; Supriyanto et al., 2020). Among the four teacher competencies, pedagogic competence becomes the leading position in the overall implementation of education and learning because teachers have a function in the learning process, and the learning process is the core of the entire educational process involving all aspects of education (Kaplan, 2018; Yulyani et al., 2020). In the pedagogic aspect, teachers must be able to make innovations in planning, implementing and evaluating learning activities so that students receive optimal education and learning so that they can grow an educated generation who can compete and have noble character (Dong et al., 2020; Khalil, 2018; Lorenza \& Carter, 2021). The difficulties faced during the outbreak should not be an excuse for teachers not to innovate in learning activities (Hamdani \& Priatna, 2020; Putria et al., 2020; Rasmitadila et 
al., 2020). Teachers can write and develop their curriculum according to their needs (Purwanto, Pramono, et al., 2020). Due to the limited interaction in learning activities, teachers must establish the best possible communication with students and parents. Several studies that have been conducted and published do not discuss in detail pedagogic competence (Dewi, 2020; Mansyur, 2020; Napsawati, 2020; Onyema, 2020; Owusu-Fordjour et al., 2020; Purwanto, Asbari, et al., 2020).

Muhammadiyah Elementary School in Purworejo Regency has been accredited A until it has not been accredited because it is a new school. Therefore, it influences the role of the principal and the competence of the teachers in it. Based on the results of interviews regarding the role of teacher pedagogic competencies from each Muhammadiyah Elementary School. At the beginning of the pandemic, teachers had difficulty teaching online, but as time went on, principals tried to upgrade teachers' abilities to become accustomed to online learning. The process of Implementingg is closely related to the pedagogic competence and the principal as a manager. The purpose of the study is to analyze the Covid-19 outbreak on changes in face-to-face learning for the online learning process from the pedagogic competence of teachers and principals as managers. This study explicitly investigates teachers and principals' pedagogical abilities to implement online learning during Covid-19, the obstacles and problems faced by teachers and principals in conducting online learning, and strategies and efforts in implementing online learning in Muhammadiyah Elementary Schools. Purworejo Regency is located in Indonesia.

\section{METHOD}

The type of research used is descriptive quantitative research. The sample in this study involved 49 teachers from four Muhammadiyah elementary schools in Purworejo Regency. The basis for the appointment of the sample, based on the level of school accreditation value. The sampling method is stratified proportional random sampling with an error rate of $10 \%$. Meanwhile, for the Principals, the sample was drawn using the proportionate stratified random sampling method, resulting in 4 Principals of Muhammadiyah Elementary Schools in Purworejo Regency based on the level of school accreditation. Data collection using a questionnaire distributed using google form. Data analysis used descriptive quantitative with percentages.

Table 1. Score Interpretation Criteria

\begin{tabular}{cc}
\hline Percentage & Interpretation \\
\hline $0 \%-20 \%$ & not good \\
$21 \%-40 \%$ & Not good \\
$41 \%-60 \%$ & pretty good \\
$61 \%-80 \%$ & Well \\
$81 \%-100 \%$ & Very good \\
\hline
\end{tabular}

Table 2. Principal Instrument Grid

\begin{tabular}{cclc}
\hline Component & Sub Component & \multicolumn{1}{c}{ Indicator } & Question Number \\
\hline & Lesson Planning & $\begin{array}{l}\text { Schools determine the curriculum } \\
\text { used in online learning. } \\
\text { The principal checks the lesson plan. } \\
\text { The principal approves or approves } \\
\text { the lesson plan. }\end{array}$ & 2 \\
Principal & Schools evaluate the online learning \\
(Manager) & Student Management & 3 & 4 \\
& $\begin{array}{l}\text { The principal determines the type of } \\
\text { application used in learning. } \\
\text { The principal facilitates support in } \\
\text { online learning. }\end{array}$ & 5 \\
\hline
\end{tabular}

Table 3. Grid of Teacher Pedagogic Competence Instruments

\begin{tabular}{cccc}
\hline Component & Sub Component & \multicolumn{1}{c}{ Indicator } & Question Number \\
\hline $\begin{array}{c}\text { Competence } \\
\text { Pedagogic }\end{array}$ & $\begin{array}{c}\text { Understanding } \\
\text { Students }\end{array}$ & $\begin{array}{l}\text { Teachers understand the physical } \\
\text { development of students } \\
\text { Teachers understand the cognitive } \\
\text { development of students }\end{array}$ & 1 \\
\hline
\end{tabular}




\begin{tabular}{|c|c|c|c|}
\hline Component & Sub Component & Indicator & Question Number \\
\hline & \multirow{14}{*}{ Learning Design } & $\begin{array}{l}\text { The teacher observes the psychomotor } \\
\text { development of students }\end{array}$ & 3 \\
\hline & & $\begin{array}{l}\text { The teacher observes the affective } \\
\text { development of students }\end{array}$ & 4 \\
\hline & & Teachers design learning tools & 5 \\
\hline & & The teacher designs the material & 6 \\
\hline & & The teacher plans the evaluation & 7 \\
\hline & & Teachers design learning methods & 8 \\
\hline & & The teacher designs the learning approach & 9 \\
\hline & & Teachers design learning models & 10 \\
\hline & & Teachers design learning resources & 11 \\
\hline & & Teachers design learning media & 12 \\
\hline & & Teachers manage study time & 13 \\
\hline & & Teachers manage student rules & 14 \\
\hline & & $\begin{array}{l}\text { The teacher manages the character of the } \\
\text { students }\end{array}$ & 15 \\
\hline & & Teachers develop the potential of students & 16 \\
\hline & \multirow{2}{*}{$\begin{array}{l}\text { Implementation of } \\
\text { Learning }\end{array}$} & $\begin{array}{l}\text { The teacher carries out the assessment of } \\
\text { learning outcomes }\end{array}$ & 17 \\
\hline & & $\begin{array}{l}\text { Teachers use assessment of learning } \\
\text { outcomes }\end{array}$ & 18 \\
\hline & \multirow{2}{*}{$\begin{array}{c}\text { Student } \\
\text { Development }\end{array}$} & Teachers use technology tools & 19 \\
\hline & & Teachers take advantage of digital platforms & 20 \\
\hline & \multirow[t]{3}{*}{$\begin{array}{l}\text { Assessment of } \\
\text { Learning } \\
\text { Outcomes }\end{array}$} & $\begin{array}{l}\text { The teacher manages the educational } \\
\text { foundation }\end{array}$ & 21 \\
\hline & & $\begin{array}{l}\text { The method used by the teacher in } \\
\text { communicating with students }\end{array}$ & 22 \\
\hline & & $\begin{array}{l}\text { Techniques used by teachers in } \\
\text { communicating with students }\end{array}$ & 23 \\
\hline & \multirow{4}{*}{$\begin{array}{l}\text { Utilization of } \\
\text { Learning } \\
\text { Technology }\end{array}$} & $\begin{array}{l}\text { The teacher conducts a competency standard } \\
\text { assessment }\end{array}$ & 24 \\
\hline & & $\begin{array}{l}\text { The teacher conducts a basic competency } \\
\text { assessment }\end{array}$ & 25 \\
\hline & & $\begin{array}{l}\text { The teacher conducts an assessment of the } \\
\text { material }\end{array}$ & 26 \\
\hline & & $\begin{array}{l}\text { The teacher conducts an evaluation of } \\
\text { learning outcomes }\end{array}$ & 27 \\
\hline
\end{tabular}

The instrument trial was conducted once on 20 teachers. After testing, the original data was tested with Corrected Item Total Correlation, this condition can be checked in the Item Statistics table, and the condition is the validity coefficient value 0.3 (Sugiyono, 2013). Validity is proven with the help of SPSS version 16.0 software. Reliability testing uses SPSS version 16 and Cronbach's Alpha technology reliability test program checked in the reliability statistics table. The reason for using Cronbach's Alpha technology is because of the 5-scale questionnaire used in the study. If the Cronbach's Alpha coefficient is more significant than 0.60, the instrument is reliable. Based on the reliability test using the SPSS version 16 software application, the results of Competence. Pedagogics is very strong (.965), and the Principal as Manager is firm (0.86).

\section{RESULT AND DISCUSSION}

\section{Result}

Based on the data processing, the Principal as the school manager determines the curriculum used in online learning during the Covid-19 period. The study results show that this indicator is in the reasonably good category with a percentage of $44 \%$. The Principal checked the learning plan during the Covid-19 period. The study results showed that this indicator was in the excellent category with a percentage of $100 \%$. The school principal ratifies or approves the learning plan during the Covid-19 period. The study 
results show that this indicator is in the outstanding category with a percentage of $100 \%$. Schools evaluate the online learning process during the Covid-19 period. The study results show that this indicator is in the excellent category with a percentage of $100 \%$. The Principal determines the type of application used in learning during the Covid-19 period. The study results show that this indicator is in the good category with a percentage of $63 \%$. The Principal facilitates support for online learning during the Covid-19 period. The study results show that this indicator is in the reasonably good category with a percentage of $50 \%$. In terms of teacher pedagogic competence in understanding the physical development of students during the Covid19 period. The study results show that this indicator is in the good category with a percentage of $62 \%$. Understanding students' cognitive development during the Covid-19 period, the study results show that this indicator is in the fairly good category with a percentage of 59\%. The results showed that this indicator was in the good category with a percentage of $61 \%$. The results showed that this indicator was in the good category with a percentage of $64 \%$. The study results show that this indicator is in the good category with a percentage of $76.5 \%$. Designing materials during the Covid-19 period, the study results show that this indicator is in the good category with a percentage of $63 \%$.

The study results show that this indicator is in the fairly good category with a percentage of $50.5 \%$. The study results show that this indicator is in the fairly good category with a percentage of $52 \%$. The results showed that this indicator was in the good category with a percentage of $68 \%$. The study results show that this indicator is in the fairly good category with a percentage of $56 \%$. The study results show that this indicator is in the good category with a percentage of $66 \%$. The study results show that this indicator is in the good category with a percentage of $70 \%$. The study results show that this indicator is in the good category with a percentage of $95 \%$. The study results show that this indicator is in the good category with a percentage of $78 \%$. The study results show that this indicator is in the good category with a percentage of $72 \%$. The study results show that this indicator is in the good category with a percentage of $61 \%$. The results showed that this indicator was in the good category with a percentage of $54.5 \%$. The results showed that this indicator was in the good category with a percentage of $69.5 \%$. The study results show that this indicator is in the good category with a percentage of $65 \%$. The results showed that this indicator was in the good category with a percentage of $69 \%$. The study results show that this indicator is in the good category with a percentage of $65.5 \%$.

The method used by teachers in communicating with students during the Covid-19 period showed that this indicator was in the excellent category with a percentage of $69 \%$. The technique used by teachers in communicating with students during the Covid-19 period, the results of the study show that this indicator is in the good category with a percentage of $64 \%$. Conducting an assessment of competency standards during the Covid-19 period, the results showed that this indicator was in a fairly good category with a percentage of $54.5 \%$. The results showed that this indicator was in the good category with a percentage of $61 \%$. The study results showed that this indicator was in a fairly good category with $56 \%$. Evaluating learning outcomes during the Covid-19 period showed that this indicator was in the good category with a percentage of $63 \%$. results Based on the research above, the indicators that will be explored further are the indicators with the lowest percentages and in general, obtained from the average value.

Table 4. Lowest Indicators of Pedagogic Competence

\begin{tabular}{ccc}
\hline No. & Indicator & Percentage \\
\hline 1 & Teachers understand the cognitive development of students & $59 \%$ \\
2 & Teachers design learning methods & $52 \%$ \\
3 & Teachers design learning models & $56 \%$ \\
4 & The teacher carries out the assessment of learning outcomes & $54,5 \%$ \\
5 & The teacher conducts an assessment of the material & $56 \%$ \\
\hline
\end{tabular}

\section{Discussion}

As a manager, the principal plays a role in carrying out management functions to achieve a goal. These functions include preparing all lesson plans, which include Prota, Promes, Silbaus, and lesson plans that support teaching and learning activities. The principal plays a role in planning (planning) related to implementation and control guidelines, determining the strategy for implementing activities, determining goals or frameworks of action to achieve the goals to be achieved (Maris et al., 2016; Muliartini et al., 2019; Ratmini et al., 2019). The organizing function is defined as dividing tasks to the people involved to facilitate the implementation of work (Ratmini et al., 2019; Yusuf, 2012). The implementation function (actuating) moves all existing elements and must be optimized to achieve the school's vision, mission, and work programs (Widodo, 2014). The controlling function is carried out to assess the planned learning plan (Wahyudin, 2018; Wuryandani et al., 2014). Based on the study results, the principal's role as manager during online learning at Muhammadiyah Elementary School Purworejo Regency has carried out its role 
well, although several roles have not been carried out optimally. In its role in examining, ratifying, and evaluating learning designs, school principals can carry out their roles to the fullest, including Prota, Promes, Syllabus, and lesson plans. Learning tools are one of the essential components in implementing learning (L. Dewi, 2017; Hartini, 2017; Prayito, 2011). Online learning activities are carried out to provide meaningful learning experiences for students without being burdened by the demands of completing all curriculum achievements (Alchamdani et al., 2020; Basith et al., 2020; Yustika et al., 2019). The role of the principal in determining the curriculum, learning applications, and providing supporting facilities for online learning by the conditions of the Covid-19 Pandemic did not play a role optimally. This is because the conditions or abilities of each school are different, so the implementation of the curriculum, applications and facilities provided is highly adapted to the school's ability.

Teachers at SD Muhammadiyah Purworejo Regency, during online learning, use the digital platforms google classroom and youtube. Google classroom is a mixed learning platform for education that can make it easier for teachers to create, share and classify each paperless assignment (Kurniawati et al., 2019; Singh et al., 2020). Google Classroom is used to maximize the process of delivering material to students, but it is done online to deliver it in its entirety (Guswara, 2020; Siahaan et al., 2021). Each school has a policy in the implementation of online learning, one of which is the implementation of the curriculum in schools, which is adjusted to the readiness and ability of the school in implementing the curriculum during online learning. The research results on pedagogic competence can be interpreted that the Muhammadiyah Elementary School teacher in Purworejo on the indicator of understanding students means that the teacher can understand students, including physical, cognitive, affective, and psychomotor well. Designing means making learning plans so that the material delivered is structured and understands the educational foundation for learning purposes (Kivunja, 2015; Nurrohmah et al., 2018; Priatmoko et al., 2021). They are carrying out learning means that teachers can maintain sufficient and conducive learning conditions for students. They were developing students' potential means that teachers can develop students to actualize their various potentials (Adiningtiyas, 2017; Supriyanto et al., 2020; Sutarto et al., 2020).

The indicator of understanding students' cognitive development during online learning, the teacher at SD Muhammadiyah Purworejo Regency gives type C3 questions. When online learning takes place, teachers have extra obstacles when choosing subject matter so that there are no misconceptions between teachers and parents when studying the material (Putria et al., 2020).On the other hand, teachers must also see the achievement of essential competencies that students must master so that the making of material when learning online must be done optimally (Kaplan, 2018; Khalil, 2018). Therefore, in this online learning, the teacher chooses to give C3 type questions to make it easier for students to do assignments. The indicator examines the material, and learning material is the content delivered in the learning process. Teachers must pay attention to the composition of information related to the needs of students in certain age groups and specific environments (Dong et al., 2020; Lorenza \& Carter, 2021). If the subjects given by the teacher do not attract the attention of students, it will reduce student activity. Usually, the teacher feels that he has mastered the subject by conveying it using language that is not even by the mental development of students. Thus, teachers will experience failure in delivering material, and vice versa, students will experience failure when receiving material (Kaplan, 2018; Khalil, 2018).

Indicators of designing learning models. Teachers at SD Muhammadiyah Purworejo Regency, during online learning, designed a problem-based learning model. Teachers who realize the importance of education in responding to the demands of the times in the era of globalization will try to equip students with the skills needed in the 21st century. Problem-based learning / PBL is formed by setting problems involving various disciplines into innovative learning theories (e.g., constructivism learning and experience) to get the right solution. PBL is one of the learning models that teachers can use to help students solve future problems and challenges (Chao et al., 2017; Fitriyanti et al., 2020; LaForce et al., 2017). Applying the problem-based learning model during the Covid-19 pandemic can improve student learning outcomes, activeness, and problem-solving abilities (Aufa et al., 2021; Davidi et al., 2021; Sakliressy et al., 2021). The impact of the Covid-19 pandemic is that the implementation of learning is carried out online or online in all elements of education (Dewantara \& Nurgiansah, 2020; Hanik, 2020; Yulia, 2020). Time, location and distance are significant issues during a pandemic. Therefore, online learning is an alternative way to overcome the difficulties of applying face-to-face learning directly (Azhari \& Fajri, 2021). Even though schools are closed, it is a challenge for all elements and levels of education to keep classes active.

\section{CONCLUSION}

The principal of SD Muhammadiyah in Purworejo Regency as a manager is included in the excellent category, although several roles and responsibilities cannot be carried out optimally. As a manager or manager, the school principal plays a crucial role in managing all school resources that support the online 
learning process so that the implementation of learning continues in the Covid-19 pandemic. In contrast, the role of pedagogic competence of Muhammadiyah elementary school teachers in Purworejo Regency is included in the excellent category.

\section{REFERENCES}

Adiningtiyas, S. W. (2017). Peran Guru dalam Mengatasi Kecanduan Game Online (Teacher's Role in Overcoming Online Game Addiction). KOPASTA: Jurnal Program Studi Bimbingan Konseling, 4(1), 28-40. https://doi.org/10.33373/kop.v4i1.1121.

Albu, G. (2013). The Teacher-headmaster and his Relationship with Himself. Procedia - Social and Behavioral Sciences, 78. https://doi.org/10.1016/j.sbspro.2013.04.369.

Alchamdani, A., Fatmasari, F., Rahmadani Anugrah, E., Putri Sari, N., Putri, F., \& Astina, A. (2020). The Impact of Covid19 Pandemic on Online Learning Process in the College at Southeast Sulawesi. Jurnal Kesehatan Lingkungan, 12(1si), 129. https://doi.org/10.20473/jkl.v12i1si.2020.129-136.

Ali, W. (2020). Online and Remote Learning in Higher Education Institutes: A Necessity in light of COVID-19 Pandemic. Higher Education Studies, 10(3), 16-25. https://doi.org/10.5539/hes.v10n3p16.

Aufa, M. N., Rusmansyah, R., Hasbie, M., Jaidie, A., \& Yunita, A. (2021). The Effect of Using e-module Model Problem Based Learning (PBL) Based on Wetland Environment on Critical Thinking Skills and Environmental Care Attitudes. Jurnal Penelitian Pendidikan IPA, 7(3), 401-407. https: //doi.org/10.29303/jppipa.v7i3.732.

Basith, A., Rosmaiyadi, R., Triani, S. N., \& Fitri, F. (2020). Investigation of Online Learning Satisfaction During COVID 19: In Relation to Academic Achievement. Journal of Educational Science and Technology (EST), 1(1), 265-275. https://doi.org/10.26858/est.v1i1.14803.

Bosica, J., S.Pyper, J., \& MacGregor, S. (2021). Incorporating problem-based learning in a secondary school mathematics preservice teacher education course. Teaching and Teacher Education, 102, 103335. https: //doi.org/10.1016/j.tate.2021.103335..

Chao, J. Y., Tzeng, P. W., \& Po, H. Y. (2017). The study of problem solving process of e-book PBL course of atayal senior high school students in Taiwan. Eurasia Journal of Mathematics, Science and Technology Education, 13(3), 1001-1012. https://doi.org/10.12973/eurasia.2017.00654a.

Darmalaksana, W., Hambali, R. Y. A., Masrur, A., \& Muhlas. (2020). Analisis Pembelajaran Online Masa WFH Pandemic Covid-19 sebagai Tantangan Pemimpin Digital Abad 21. Karya Tulis Ilmiah (KTI) Masa Work From Home (WFH) Covid-19 UIN Sunan Gunung Djati Bandung Tahun 2020, 1(1), 1-12.

Davidi, E. I. N., Sennen, E., \& Supardi, K. (2021). Integrasi Pendekatan STEM (Science, Technology, Enggeenering and Mathematic) Untuk Peningkatan Keterampilan Berpikir Kritis Siswa Sekolah Dasar. Scholaria: Jurnal Pendidikan Dan Kebudayaan, 11(1), 11-22. https: //doi.org/10.24246/j.js.2021.v11.i1.p11-22.

Dewantara, J. A., \& Nurgiansah, T. H. (2020). Efektivitas Pembelajaran Daring di Masa Pandemi COVID 19 Bagi Mahasiswa Universitas PGRI Yogyakarta. Jurnal Basicedu, 5(1), 367-375. https: //doi.org/10.31004/basicedu.v5i1.669.

Dewi, L. (2017). Rancangan Program Pembelajaran Daring Di Perguruan Tinggi: Studi Kasus Pada Mata Kuliah Kurikulum Pem-Belajaran Di Universitas Pendidikan Indonesia. Edutech, 16(2), 205. https: //doi.org/10.17509/e.v16i2.7616.

Dewi, W. A. F. (2020). Dampak COVID-19 terhadap Implementasi Pembelajaran Daring di Sekolah Dasar. Jurnal Edukatif Ilmu Pendidikan, 2(1). https://doi.org/10.31004/edukatif.v2i1.89.

Dhawan, S. (2020). Online Learning: A Panacea in the Time of COVID-19 Crisis. Journal of Educational Technology Systems, 49(1), 5-22. https://doi.org/10.1177/0047239520934018.

Dong, C., Cao, S., \& Li, H. (2020). Young children's online learning during COVID-19 pandemic: Chinese parents' beliefs and attitudes. Children and Youth Services Review, 118(June), 105440. https: //doi.org/10.1016/j.childyouth.2020.105440.

Fitriyanti, F., Farida, \& Zikri, A. (2020). Peningkatan Sikap dan Kemampuan Berpikir Ilmiah Siswa Melalui Model PBL di Sekolah Dasar. Jurnal Basicedu, 4(2). https://doi.org/10.31004/basicedu.v4i2.376.

Guswara, A. M. (2020). The Contribution of Google Classroom Application and Motivation to The Learning Outcomes of Web Programming. Educational Technology, 4(4), 1-9. https: //doi.org/10.23887/jet.v4i4.29896.

Hamdani, A. R., \& Priatna, A. (2020). Efektivitas Implementasi Pembelajaran Daring (Full Online) Dimasa Pandemi Covid-19. VI, 1-9.

Hanik, E. U. (2020). Self directed learning berbasis literasi digital pada masa pandemi covid-19 di Madrasah Ibtidaiyah. ELEMENTARY: Islamic Teacher Journal, 8(1), 183. https://doi.org/10.21043/elementary.v8i1.7417. 
Hartini, A. (2017). Pengembangan Perangkat Pembelajaran Model Project Based Learning Untuk Meningkat Kemampuan Berpikir Kritis Siswa Sekolah Dasar. Jurnal Pendidikan Dan Pembelajaran Di Sekolah Dasar, 1(2). https: //doi.org/10.30651/else.v1i2a.1038.

Huang, K., Wu, Y., Long, C., Ji, H., \& Sun, B. (2021). Adaptive process monitoring via online dictionary learning and its industrial application. ISA Transactions, 114. https://doi.org/10.1016/j.isatra.2020.12.046.

Hutauruk, A., \& Sidabutar, R. (2020). Kendala pembelajaran daring selama masa pandemi di kalangan mahasiswa pendidikan matematika: Kajian kualiatatif deskriptif. Journal of Mathematics Education and Applied, 02(01), 45-51. https://doi.org/10.36655/sepren.v2i1.364.

Ikbal, I., Taena, L., \& Ilham, M. (2019). Faktor Penyebab Rendahnya Hasil Belajar Siswa Kelas XI Pada Mata Pelajaran Ekonomi Di SMA Negeri 1 Bone Kabupaten Muna. Jurnal Online Program Studi Pendidikan Ekonomi, 4(1). https://doi.org/10.36709/jopspe.v4i1.13526.

Ingemarson, M., Rubenson, B., Bodin, M., \& Guldbrandsson, K. (2014). Implementation of a school-wide prevention programme-teachers' and headmasters' perceptions of organizational capacity. Evaluation and Program Planning, 43. https://doi.org/10.1016/j.evalprogplan.2013.10.005.

Kadarsih, Inge. Marsidin, Sufyarma. Subandi Ahmad, F. A. E. (2020). Peran dan Tugas Kepemimpinan Sekolah di Sekolah Dasar. Jurnal Ilmiah Ilmu Pendidikan, 2(2), 194. https: //doi.org/10.31004/edukatif.v2i2.138.

Kaplan, D. E. (2018). Piagetian Theory in Online Teacher Education. Scientific Research Publishing, 9(6). https://doi.org/10.4236/ce.2018.96061.

Khalil, Z. M. (2018). EFL Students' Perceptions towards Using Google Docs and Google Classroom as Online Collaborative Tools in Learning Grammar. Applied Linguistics Research Journal, 2(2), 33-48. https://doi.org/10.14744/alrj.2018.47955.

Kimkong Heng, \& Koemhong Sol. (2020). Online learning during COVID-19: Key challenges and suggestions to enhance effectiveness. Cambodian Education Forum (CEF), December, 1-15. https: //doi.org/10.1371/journal.pone.0248758.

Kivunja, C. (2015). Unpacking the Information, Media, and Technology Skills Domain of the New Learning Paradigm. International Journal of Higher Education, 4(1). https://doi.org/10.5430/ijhe.v4n1p166

Korkmaz, G., \& Toraman, C.. (2020). Are We Ready for the Post-COVID-19 Educational Practice? An Investigation into What Educators Think as to Online Learning. International Journal of Technology in Education and Science, 4(4), 293-309. https://doi.org/10.46328/ijtes.v4i4.110.

Kurniawati, M., Santanapurba, H., \& Kusumawati, E. (2019). Penerapan Blended Learning Menggunakan Model Flipped Classroom Berbantuan Google Classroom Dalam Pembelajaran Matematika Smp. EDU-MAT: Jurnal Pendidikan $\quad$ Matematika, https: //doi.org/10.20527/edumat.v7i1.6827.

LaForce, M., Noble, E., \& Blackwell, C. (2017). Problem-Based Learning (PBL) and Student Interest in STEM Careers: The Roles of Motivation and Ability Beliefs. Education Sciences, 7(4), 92. https: //doi.org/10.3390/educsci7040092.

Lorenza, L., \& Carter, D. (2021). International Journal of Educational Research Open Emergency online teaching during COVID-19: A case study of Australian tertiary students in teacher education and creative arts. International Journal of Educational Research Open, 2-2(May), 100057. https://doi.org/10.1016/j.ijedro.2021.100057.

Mahmoodi, M., Rashtchi, M., \& Abbasian, G. R. (2019). Evaluation of in-service teacher training program in iran: Focus on the Kirkpatrick model. Education and Self Development, 14(4), 20-38. https://doi.org/10.26907/esd14.4.03.

Mansyur, A. R. (2020). Dampak COVID-19 Terhadap Dinamika Pembelajaran Di Indonesia. Education and Learning Journal, 1(2), 113. https://doi.org/10.33096/eljour.v1i2.55.

Maris, I. S., Komariah, A., \& Bakar, A. (2016). Kepemimpinan Transformasional Kepala Sekolah, Kinerja Guru Dan Mutu Sekolah. Jurnal Administrasi Pendidikan, 23(2), 173-188. https://doi.org/10.17509/jap.v23i2.5645.

Maulana, H. A., \& Hamidi, M. (2020). Persepsi Mahasiswa terhadap Pembelajaran Daring pada Mata Kuliah Praktik di Pendidikan Vokasi. Equilibrium: Jurnal Pendidikan, 8(2), 224-231. https: //doi.org/10.26618/equilibrium.v8i2.3443.

Mpungose, C. B. (2021). Lecturers' reflections on use of Zoom video conferencing technology for e-learning at a South African university in the context of coronavirus. African Identities. https: //doi.org/10.1080/14725843.2021.1902268.

Muliartini, Natajaya, \& Sunu. (2019). Kontribusi Kepemimpinan Kepala Sekolah, Etos Kerja, Kepuasan Kerja, dan Budaya Organisasi Sekolah Terhadap Kinerja Guru di SMKN 2 Singaraja. Jurnal Administrasi Pendidikan Indonesia, 10(1), 13-23. https://doi.org/10.23887/japi.v10i1.2786.

Mustikaningrum, G., Pramusinta, L., Ayu, S., \& Umar, M. (2020). Implementasi Pendidikan Karakter 
Terintegrasi Kurikulum Dan Metode Pembelajaran Pada Masa Pandemi Covid-19. AULADUNA: $\begin{array}{lllll}\text { Jurnal Pendidikan } & \text { Dasar } & \text { Islam, } & \text { 154-164, }\end{array}$ https://doi.org/10.24252/10.24252/auladuna.v7i2a5.2020.

Napsawati, N. (2020). Analisis Situasi Pembelajaran Ipa Fisika Dengan Metode Daring Di Tengah Wabah Covid-19. Karst: JURNAL PENDIDIKAN FISIKA DAN TERAPANNYA, 3(1), 96-102. https: //doi.org/10.46918/karst.v3i1.546.

Nurkholis, I. (2021). Analisis Kelebihan dan Kekurangan dalam Pembelajaran Daring di SDN Pesanggrahan 01 Kota Batu Malang. PTK: Jurnal Tindakan Kelas, 2(1), 84-89. https://doi.org/10.53624/ptk.v2i1.45.

Nurrohmah, F., Putra, F. G., \& Farida, F. (2018). Development of Sparkol Video Scribe Assisted Learning Media. Formatif: Jurnal Ilmiah Pendidikan MIPA, 8(3), 233-250. https://doi.org/10.30998/formatif.v8i3.2613.

Onyema, E. M. (2020). Impact of Coronavirus Pandemic on Education. Journal of Education and Practice, 11(13), 108-121. https://doi.org/10.7176/jep/11-13-12.

Owusu-Fordjour, C., Koomson, C. K., \& Hanson, D. (2020). European Journal of Education Studies The Impact Of Covid-19 On Learning -. European Journal of Education Studies, 7(3), 88-101. https://doi.org/10.5281/zenodo.3753586.

Prayito. (2011). Pengembangan Perangkat Pembelajaran Matematika Humanistik Berbasis Konstruktivisme Berbantuan E-Learning Materi Segitiga Kelas VII. AKSIOMA Journal of Mathematics Education, 2(2). https://doi.org/10.26877/aks.v2i2/Septembe.37.

Priatmoko, S., Sugiri, W. A., Bashori, \& Islamy, M. I. (2021). Distance Learning for New Students in the Era of Pandemic Coronavirus Disease (Covid-19): Implementation and Barriers. Proceedings of the International Conference on Engineering, Technology and Social Science (ICONETOS 2020), 529(Iconetos 2020), 607-613. https://doi.org/10.2991/assehr.k.210421.088.

Purwanto, A., Asbari, M., Fahlevi, M., Mufid, A., Agistiawati, E., Cahyono, Y., \& Suryani, P. (2020). Impact of Work From Home (WFH) on Indonesian Teachers Performance During the Covid-19 Pandemic : An Exploratory Study. International Journal of Advanced Science and Technology, 29(5), 6235-6244.

Purwanto, A., Pramono, R., Asbari, M., Hyun, C. C., Wijayanti, L. M., Putri, R. S., \& Santoso, priyono B. (2020). Studi Eksploratif Dampak Pandemi Covid-19 Terhadap Proses Pembelajaran Online di Sekolah Dasar. Jurnal of Education, Psychology and Counseling., 2(1).

Putria, H., Maula, L. H., \& Uswatun, D. A. (2020). Analisis Proses Pembelajaran dalam Jaringan (DARING) Masa Pandemi Covid- 19 Pada Guru Sekolah Dasar. Jurnal Basicedu, 4(4), 861-872. https://doi.org/10.31004/basicedu.v4i4.460.

Rasmitadila, Aliyyah, R. R., Rachmadtullah, R., Samsudin, A., Syaodih, E., Nurtanto, M., \& Tambunan, A. R. S. (2020). The Perceptions of Primary School Teachers of Online Learning during the COVID-19 Pandemic Period : A Case Study in Indonesia. Journal of Ethnic and Cultural Studies, 7(2), 90-109. https://doi.org/http://dx.doi.org/10.29333/ejecs/388.

Ratmini, N. A., Natajaya, I. N., \& Sunu, I. G. K. A. (2019). Kontribusi Gaya Kepemimpinan Kepala Sekolah, Komitmen Organisasi, Iklim Kerja dan Motivasi Kerja Terhadap Kinerja Guru SMP Negeri 2 Singaraja. Jurnal Administrasi Pendidikan Indonesia, 10(2), 91-100. https: //doi.org/10.23887/japi.v10i2.2795.

Rigianti, H. A. (2020a). Kendala Pembelajaran Daring Guru Sekolah Dasar Di Banjarnegara. Elementary School: Jurnal Pendidikan Dan Pembelajaran Ke-SD-An, 7(2). https://doi.org/10.31316/esjurnal.v7i2.768.

Rigianti, H. A. (2020b). Kendala Pembelajaran Daring Guru Sekolah Dasar di Kabupaten Banjarnegara. Orphanet Journal of Rare Diseases, 21(1), 1-9. https://doi.org/10.31316/esjurnal.v7i2.768.

Roni Hamdani, A., \& Priatna, A. (2020). Efektifitas Implementasi Pembelajaran Daring (Full Online) Dimasa Pandemi Covid- 19 Pada Jenjang Sekolah Dasar Di Kabupaten Subang. Didaktik : Jurnal Ilmiah PGSD STKIP Subang, 6(1), 1-9. https://doi.org/10.36989/didaktik.v6i1.120.

Sakliressy, M. T., Sunarno, W., \& Nurosyid, F. (2021). Students Scientific Attitude in Learning Physics Using Problem Based Learning Model with Experimental and Project Methods. Jurnal Ilmiah Pendidikan Fisika Al-Biruni. https://doi.org/10.24042/jipfalbiruni.v10i1.8347.

Siahaan, K. W. A., Manurung, H. M., \& Siahaan, M. M. (2021). Android-Based Learning Media Development Strategies During Pandemic Times To Improve Student Science Literature. International Journal of Education and Humanities, 1(1), 34-42.

Singh, C. K. S., Singh, T. S. M., Abdullah, N. Y., Moneyam, S., Ismail, M. R., Tek, E., Karupayah, T., Chenderan, K., Singh, M. K. R., \& Singh, J. K. S. (2020). Rethinking English language teaching through Telegram, Whatsapp, Google classroom and Zoom. Systematic Reviews in Pharmacy, 11(11), 45-54. https://doi.org/10.31838/srp.2020.11.9. 
Subandi, S. (2018). Kontribusi Kepemimpinan Kepala Sekolah, Motivasi Kerja,dan Iklim Sekolah terhadap Kinerja Guru. Jurnal Penelitian Dan Pengembangan Sains Dan Humaniora, 1(2), 57-63. https://doi.org/10.23887/jppsh.v1i2.12934.

Sugiyono. (2013). Metode Penelitian Pendidikan. In Alfabeta.

Supriyanto, A., Hartini, S., Irdasari, W. N., Miftahul, A., Oktapiana, S., \& Mumpuni, S. D. (2020). Teacher professional quality: Counselling services with technology in Pandemic Covid-19. Counsellia: Jurnal Bimbingan Dan Konseling, 10(2), 176. https://doi.org/10.25273/counsellia.v10i2.7768.

Sutarto, S., Sari, D. P., \& Fathurrochman, I. (2020). Teacher Strategies in Online Learning to Increase Students ' Interest in Learning During CoVID-19 Pandemic. Jurnal Konseling Dan Pendidikan, 8(147800), 129-137. https://doi.org/10.29210/147800.

Taştan, S. B., Davoudi, S. M. M., Masalimova, A. R., Bersanov, A. S., Kurbanov, R. A., Boiarchuk, A. V., \& Pavlushin, A. A. (2018). The impacts of teacher's efficacy and motivation on student's academic achievement in science education among secondary and high school students. Eurasia Journal of Mathematics, Science and Technology Education, 14(6), 2353-2366. https://doi.org/10.29333/ejmste/89579.

Wahyudin, W. (2018). Optimalisasi Peran Kepala Sekolah dalam Implementasi Kurikulum 2013. Jurnal Kependidikan, 6(2), 249-265. https://doi.org/10.24090/jk.v6i2.1932.

Widodo. (2014). Strategi Peningkatan Aktivitas Jasmani Siswa Sekolah Dasar di Luar Pembelajaran Pendidikan Jasmani, Olahraga, dan Kesehatan di Indonesia. Jurnal Pendidikan Dan Kebudayaan, 20(2), 281-294. https://doi.org/10.24832/jpnk.v20i2.144.

Wijaya, T. T., Ying, Z., Purnama, A., \& Hermita, N. (2020). Indonesian students' learning attitude towards online learning during the coronavirus pandemic. Psychology, Evaluation, and Technology in Educational Research, 3(1). https://doi.org/10.33292/petier.v3i1.56.

Wuryandani, W., Maftuh, B., Sapriya, \& Budimansyah, D. (2014). Pendidikan Karakter Disiplin Di Sekolah Dasar. Jurnal Cakrawala Pendidikan, 2(2), 286-295. https://doi.org/10.21831/cp.v2i2.2168.

Yahdiyani, N. R., Muna, A. R., Nurjanah, S., \& Wahyuni, S. (2020). Peran Kepemimpinan Kepala Sekolah dalam Meningkatkan Kualitas Peserta didik di SDN Martapuro 2 Kabupaten Pasuruan. Journal of Education, Psychology and Counseling, 02(01), 327-336.

Yulia, H. (2020). Online Learning to Prevent the Spread of Pandemic Corona Virus in Indonesia. ETERNAL (English Teaching Journal), 11(1). https://doi.org/10.26877/eternal.v11i1.6068.

Yulyani, Y., Kazumaretha, T., Arisanti, Y., Fitria, Y., \& Desyandri, D. (2020). Implementasi Kompetensi Pedagogik Guru Dalam Pembelajaran Tematik Di Sekolah Dasar. School Education Journal Pgsd Fip Unimed, 10(2), 184. https://doi.org/10.24114/sejpgsd.v10i2.18545.

Yustika, G. P., Subagyo, A., \& Iswati, S. (2019). Masalah Yang Dihadapi Dunia Pendidikan Dengan Tutorial Online: Sebuah Short Review. Tadbir: Jurnal Studi Manajemen Pendidikan, 3(2), 195. https://doi.org/10.29240/jsmp.v3i2.1178.

Yusuf, M. (2012). Kinerja Kepala Sekolah dan Guru dalam Mengimplementasikan Pendidikan Inklusif. Jurnal Pendidikan Dan Kebudayaan, 18(4). https://doi.org/10.24832/jpnk.v18i4.96.

Zhou, S., Shearing, P. R., Brett, D. J. L., \& Jervis, R. (2021). Machine learning as an online diagnostic tool for proton exchange membrane fuel cells. Current Opinion in Electrochemistry, 23. https://doi.org/10.1016/j.coelec.2021.100867. 